\title{
Paediatrics is a big player of COVID-19 in Hong Kong
}

Hong Kong Med J 2020;26:265-6

https://doi.org/10.12809/hkmj208546

To the Editor-As of 23 April 2020, there have been 104 confirmed paediatric cases of coronavirus disease 2019 (COVID-19) in Hong Kong. Fortunately, all cases were mild or asymptomatic with no fatalities. ${ }^{1}$ The proportion of patients with COVID-19 who are aged $\leq 19$ years is $14.1 \%$ in Hong Kong, which is higher than other countries (Table). ${ }^{1-6}$ This may be attributable to high numbers of overseas students returning to Hong Kong; even those who are asymptomatic are tested as part of the current border controls. Mortality for patients aged $\leq 19$ years is very low, with less than 10 reported cases, mostly teenagers. ${ }^{7-9}$

Current clinical management of COVID-19 is mainly supportive and there are currently no definite antiviral drugs recommended for the treatment of paediatric patients with COVID-19.? The Hong Kong College of Paediatricians and The Hong Kong Society of Paediatric Immunology Allergy and Infectious Disease have taken a leading role in paediatric public health promotions, and published a very clear and informative guidance for parents to refer to in prevention of COVID-19, with links to educational materials that will help children understand the current situation of this epidemic. ${ }^{10}$ Children should be engaged in usual preventive actions to avoid infection, including cleaning hands often using soap and water or alcohol-based hand sanitiser, avoiding contact with others who display COVID-19 symptoms, and staying up to date on vaccinations, including influenza vaccine.

In response to the COVID-19 pandemic, schools in Hong Kong were closed from 25 January 2020, resulting in psychosocial crises in schooling, examinations, and related childhood and paediatric routines. ${ }^{11}$ Many challenging decisions have been made to manage these crises while children are home-bound. Teaching has been partially resumed with online teaching, examinations have been postponed, modes of examinations have been modified, and formal schooling will only be resumed when there is evidence that the spread of COVID-19 is slowing or stopped. Although children fare better after infection, they may serve as vectors of viral transmission in the community. Specific interventions implemented to reduce such risks include quarantining and rigorous screening of asymptomatic or silent carriers. Isolation facilities have to be provided to contain and treat these relatively well infected patients, so that airborne infection isolation rooms can be reserved for more seriously affected patients. Although there is no robust evidence that lactating mothers spread the virus more easily than others, for those who are healthcare personnel working in high-risk areas, it may be prudent to switch them temporarily to lower-risk posts to reduce the risks of contracting the virus.

The next challenge for Hong Kong is to resume socio-economic activities whilst suppressing the outbreak of potential cases in the community. Children and young adults may be a big driver in the 'second wave' of the COVID-19 outbreak in Hong Kong, and appropriate measure should be taken to minimise this risk.

\section{Author contributions}

All authors contributed to the concept or design of the study, acquisition of the data, analysis or interpretation of the data, drafting of the manuscript, and critical revision of the manuscript for important intellectual content. All authors had full access to the data, contributed to the study, approved the final version for publication, and take responsibility for its accuracy and integrity.

\section{Conflicts of interest}

The authors have no conflicts of interest to disclose.

TABLE. Patients with coronavirus disease 2019 (COVID-19) aged $\leq 19$ years (as of 22 Apr 2020)*

\begin{tabular}{lcccccc}
\hline & Hong Kong & $\begin{array}{c}\text { Mainland } \\
\text { China }^{2}\end{array}$ & Singapore $^{3}$ & South Korea & $\begin{array}{c}\text { United } \\
\text { States }^{5}\end{array}$ & Italy $^{\mathbf{6}}$ \\
\hline Total COVID-19 cases in the study population & 1034 & $72314 \dagger$ & 802 & 9037 & 149082 & 20686 \\
Age 0-19 years & $146(14.1 \%)$ & $965(1.3 \%) \dagger$ & $38(4.7 \%)$ & $573(6.3 \%)$ & $2572(1.7 \%) \ddagger$ & $268(1.3 \%)$ \\
Mortality & 0 & 0 & 0 & 0 & 3 & 0 \\
\hline
\end{tabular}

* Patients up to 19 years old were included as most cities/countries report data with this age range

+ Include suspected COVID-19 cases

$\neq$ Include patients $<18$ years 


\section{Funding/support}

This letter received no specific grant from any funding agency in the public, commercial, or not-for-profit sectors.

KL Hon *, MB, BS, MD

Karen KY Leung, MB, BS, MRCPCH

Department of Paediatrics and Adolescent Medicine, The Hong Kong Children's Hospital, Hong Kong

*Corresponding author: ehon@hotmail.com

\section{References}

1. Centre for Health Protection, Hong Kong SAR Government. Latest situation of cases of COVID-19. Available from: https://www.chp.gov.hk/files/pdf/local situation_covid19_en.pdf. Accessed 23 Apr 2020.

2. Wu Z, McGoogan JM. Characteristics of and important lessons from the coronavirus disease 2019 (COVID19) outbreak in China: Summary of a report of 72314 cases from the Chinese Center for Disease Control and Prevention. JAMA 2020;323:1239-42.

3. Ministry of Health Singapore. Official update of COVID19 situation in Singapore. 2020 Available from: https:// covidsitrep.moh.gov.sg/. Accessed 29 Mar 2020.

4. Korean Centers for Disease Control and Prevention. The updates on COVID-19 in Korea as of 24 March. Available from: https://www.cdc.go.kr/board/board.es?mid=a30402 000000\&bid $=0030 \&$ act $=$ view\&list $\_$no $=366633$. Accessed
24 Mar 2020.

5. CDC COVID-19 Response Team. Coronavirus disease 2019 in children-United States, February 12-April 2, 2020. MMWR Morb Mortal Wkly Rep 2020;69:422-6.

6. Istituto Superiore di Sanità. Epidemia COVID-19 [in Italian]. Available from: https://www.epicentro.iss.it/ coronavirus/bollettino/Bollettino sorveglianza integrata COVID-19_19-marzo 2020.pdf. Accessed 28 Mar 2020.

7. Shen K, Yang Y, Wang T, et al. Diagnosis, treatment, and prevention of 2019 novel coronavirus infection in children: experts' consensus statement. World J Pediatr 2020 Feb 7. Epub ahead of print.

8. Lu X, Zhang L, Du H, et al. SARS-CoV-2 infection in children. N Engl J Med 2020;382:1663-5.

9. Dong $\mathrm{Y}, \mathrm{Mo} \mathrm{X}, \mathrm{Hu} \mathrm{Y}$, et al. Epidemiological characteristics of 2143 pediatric patients with 2019 coronavirus disease in China. Pediatrics 2020 Mar 16. Epub ahead of print.

10. Hong Kong College of Paediatricians and Hong Kong Society for Paediatric Immunology Allergy and Infectious Diseases. Prevention of novel coronavirus infection, recommendations for parents. 5 February 2020. Available from: http://www.paediatrician.org. hk/index.php?option $=$ com_docman\&task $=$ doc view\&gid=1768\&Itemid=66. Accessed 22 Apr 2020.

11. Hong Kong SAR Government. SED opening remarks at press conference on measures against novel coronavirus infection. 25 January 2020. Available from: https://www. info.gov.hk/gia/general/202001/25/P2020012500583.htm. Accessed 10 May 2020. 